特別講演

\title{
日本写真測量学会秋季学術講演会・特別講演 「我が国の自然環境」
}

環境とは定義しにくい概念であるが, 要するに我々 の周囲，周りのことであって，これを涊識する主体， すなわち人間の存在があってはじめて成り立つ概念で ある。色々と定義されているが，ここでは日本の自然 環境について述べる。

通常我々日本人が自然環境として認識しているもの は「二次的自然」と呼ばれるもので，人との関わりに よって創られ，人が関与することで維持保全される自 然であって, 通常「里山」と呼ばれるものであるが, この自然環境はどのようにして形成されてきたのであ ろうか。

文化・文明は農業と共に発生し，発達してきた。食 料を効率よくあるいは組織的に手に入れるための営為 である農業には定住することと知識や技術を持つこと が必要であることは明らかであって，この故に「農業・ 農耕」が文明あるいは文化のもととなったのである。 この事は，「文化・教養」を意味する英語の “culture” に「耕作」の意味があり，その語源は中世以来20世紀 初頭まで教会や大学で使われてきたラテン語の「耕す, 培う，耕地」という意味の“cultura”という言葉であ ることからも分かる。

日本の農業の特徵は本来「稲作農業」だということ である。稲そのものは数千年前の縄文時代にいわゆる 「海上の道 (南西諸島経由)」を通って陸稲（熱带ジャ ポニカ）が中国から渡来し，焼畑で栽培されていた。 すなわち熱带ジャポ二カは「縄文の稻」なのである。 ちなみに「畑」は火で作る耕地を意味する文字である。 BC2500年頃から急速な寒泠化が始まって海面が低下 し(縄文海退), 日本の人口は急減した。BC 1000 年頃に は現在程度の海面となって広大な湿地带が発生した

2006年11月23日松江テルサで行われた秋季学術講演会・特 別講演をまとめたものである。

「写真測量とリモートセンシング」VOL. 45，NO. 6，2006

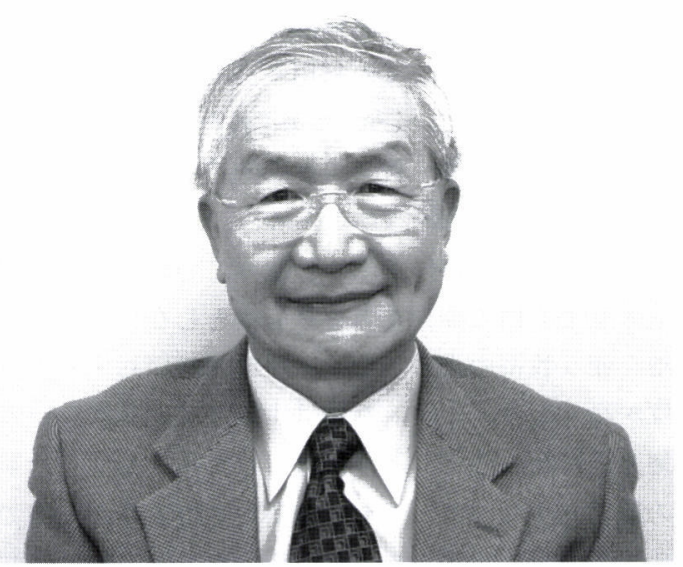

が,この頃になると大陸の長江流域から水稲(温帯ジャ ポニカ）とその栽培技術がもたらされ，1万年以上続 いた縄文時代は弥生時代へ移る。

弥生時代は稲作文化と共に始まった。また水田稲作 の技術と共に青銅器, 鉄器が伝わり, 日本の金属器時 代の始まりともなった。弥生時代の開始年代について はまだ定説がないが, 最新の $\mathrm{C}_{14}$ による結果では $\mathrm{BC} 10$ c 後半とされているので, ここではこれに従う。中国で はほぼ殷（商）の滅亡, 西周の成立の頃で, 西周の滅 亡，春秋時代，戦国時代，三国時代と続く動乱の時代 であり, 戦乱を避けて多くの人々が渡来したと考えら れている。すなわち，水田稲作の技術体系(稲作文化) を持った人々のグループが渡来したのであり, 水稲は, 一つは長江（揚子江）流域から直接海を渡って，一つ は朝鮮半島を経由してという二つのルートで九州北部 へ伝わったとされている。渡来した熱带・温带の両ジャ ポニカは晚生であったが, この二品種が自然交雑して 早生の水稲が生まれ，これが驚くべきスピードで全国 に広まったのである。BC600年頃には近畿地方に達し， BC300年頃には青森に達したと考えられている。この ようにして大陸からやって来た人々と縄文の人々とが 
合体して形成した新文化が弥生文化でなのである。 水田稲作の特徵は，畦畔（あぜ）で井まれた特別な 農地と多量の水, すなわち水田と灌溉用水が必要で, さらに水を平等に配るための複雑な水路や水利慣行, 及びこれらための技術が必要なことである。山や森は この水を安定して供給する緑のダムであり, このため 水神を祀り, 水源地の山や森は神の山, 鎮守の森といっ た形で保護したことが現在日本が世界有数の森林国で ある（森林率66.5\%）ことの大きな理由である。農業 用水路の水は灌溉のみならず農作物や農機具の洗浄等 の農作業に, さらには生活用水として衣類や食器の洗 浄や防火用水等としても利用されて, 農業用水の10倍 ほどの水が流れている地域の用水であった。このよう に, 水丒稲作は水・緑・土と共生する, 共生しなけれ ばならない農耕技術なのである。

さらに，米 (特に立米) を食べていれぱ栄養のバラ ンスもよく他の副食をあまり必要としないので広い用 地を使う牧畜の必要がなく，耕地面積に対する人口密 度が高くなる。また, 水田は土塞侵食を受けないので 地力維持が容易で, 連作障害 (イヤ地) もなく, 旱魃 の被害も少ないことから永続的な食糧生産が可能であ る。この水田の安定した高い生産性と米（粐）の販蔵 性の良さから耕作地近くへの定住化と人口の集中化が 生じた。縄文末期に急減した日本の人口は弥生時代に 入って数十万人にまで急増したといわれる。また，田 植や収穫, 水管理等にあたっては村を挙げて協力する 必要があることから村を単位とした共同体が生まれた が, 一方, 水田という永続的な農業施設をめぐって所 有権等の権力の発生や階級の分化が見られるようにな ク, さらには領土・領地という概念とそれに伴う権力 の集中や争いも生じたと考えられている。戦争は弥生 時代になって見られるようになったものなのである。

このように，稲作文化は水と緑と土の文化であり， 我々は長い年月にわたって水・緑・土と共生し，その
過程で稲作文化独特の生活環境, 自然環境を作り上げ てきた。それが, いわゆる水田と山林がセットとなっ た「里山」と呼ばれる自然環境であって，里山の景観 は日本人の原風景となっている。広い意味では平地林, 畑や小川, さらには集落をも含んだ概念あって,「里地」 ともいう。また，人間が創り，人間が保全(維持管理) を行っている自然であることから「二次的自然」と称 するのである。つまり,農村地域の自然環境は人間あっ てのものであり，だからこそ農村部に人が住む，住み 続けることが大切なのである。

近代になって西欧の文化が取り入れられて都市が農 村を侵食するまでは，我が国の文化は水・緑・土と共 生する稲作文化そのものであった。僅か140年足らずの 西欧の都市文化に対して，稲作文化は約3000年の長い 年月にわたって日本人のアイデンティティを形成して きたのであり，我が国固有の文化や環境，景観は農耕 民族である日本人の歴史が形成してきたものなのであ る。

最後に稲作文化が現在の日本の深層文化となってい ることの例を少し挙げておくと, 稲の成長過程に応じ た農耕儀礼に伴って田植えや収穫に由来する種々のお 祭りが生まれ, 田の神, 水の神, 鎮守, 産土神, 稲荷 などの神社が生まれた。また，雪形（残雪や露出した 岩肌の形）にさまざまな名前を付けて農作業や漁業の 目安としたが, これに由来する山の名前も, 駒ヶ岳, 爺ヶ岳, 白馬岳, 蝶ヶ岳, 燕岳など多く存在している。 さらに，天皇家は稲作と養虫を行う農家であって，田 植之や稲朾り, 虫の給桑や上蔟等の農作業はもとより, 新嘗祭, 神嘗祭, 天皇即位の際の大嘗祭等の収穫祭が 行われていることは広く知られているとおりである。

これらは，日本の文化が基本的に稲作中心の農耕に 基盤を置いている稲作文化であることの現れなのであ る。 